\title{
PNEUMOCOCCIC PNEUMONIA: THE PROGNOSTIC SIGNIFICANCE OF THE NUMBER OF PNEUMOCOCCI IN THE SPUTUM IN RELATION TO THERAPY, BACTEREMIA, TYPE, LEUKO- CYTE COUNT, DURATION OF THE DISEASE, AGE, AND DEGREE OF INVOLVEMENT ${ }^{1}$
}

\author{
By ARTHUR W. FRISCH, ALVIN E. PRICE, AND GORDON B. MYERS \\ (From the Departments of Bacteriology and Internal Medicine, Wayne University College of \\ Medicine, and Receiving Hospital, Detroit)
}

(Received for publication September 15, 1942)

A study of Wright-stained smears of rusty sputum from patients with pneumonia has revealed that the number of pneumococci per oil immersion field may be used as a reliable aid in prognosis (1). Furthermore, the specific response of individual patients to serum and to sulfonamides can be readily followed by examination of sputum at intervals during the course of the disease. While the end result of both of these forms of therapy is a reduction in the number of organisms in the sputum and in the lungs (2), this is accomplished in a different manner by each of the therapeutic agents. Adequate serum, in moderately ill patients, brings about a prompt agglutination of the pneumococci in the sputum within 6 to 12 hours. This is usually folowed by phagocytosis and a gradual reduction in the number of organisms over a period of several days $(3,4)$. The sulfonamides, on the other hand, exert a direct bacteriostatic effect which is manifested by a reduction in the number of pneumococci within 12 to 36 hours. A striking decrease is obtained in the sputum, regardless of the number originally present, except in rare instances where drug-fastness develops $(3,5,6)$. In this communication, the sputum counts will be compared as to prognostic significance with the time honored clinical and laboratory criteria, such as type, bacteremia, duration of disease, leukocyte count, age, and degree of involvement.

\section{METHOD}

Specimens were obtained from patients on admission to the hospital and at 12-hour intervals throughout the period of production of rusty or bloody sputum. Thin smears were made directly from representative rusty portions and were immediately treated with Wright's blood

1 Supported by a grant from the Commonwealth Fund to the Michigan Department of Health Laboratories. stain for 3 to 5 minutes. 2 The stain was flooded off without the addition of buffer and the slides were air dried. The capsules of the pneumococci were usually visualized as clear or occasionally as pink zones around the dark blue diplococci. The mucin stained pale pink and the leukocytes and red blood cells were differentiated as on a blood smear.

The necessity of obtaining good specimens of sputum directly from the patient cannot be overemphasized. Rusty sputum, relatively free of organisms other than pneumococci, gave the most consistent results. Satisfactory specimens were obtained from 90 per cent of the type I through VIII pneumonias. The remaining 10 per cent of the cases failed to produce rusty sputum and were, therefore, excluded from the study. Frankly purulent specimens contained large number of pneumococci which bore little relation to the clinical course or outcome of the pneumonia. Watery mucoid sputum usually showed so many contaminating mouth organisms and desquamated epithelial cells that they had to be discarded.

The average number of extracellular encapsulated pneumococci was determined by counting 10 widely separated fields on the slide. A microscopic field was considered suitable for counting if it contained 10 to 15 leukocytes or red blood cells, if organisms other than pneumococci were absent, and if the capsules of the pneumococci were distinctly visible. When good specimens of sputum were obtained, the counts increased or decreased progressively; sudden changes in the number per field were found to be primarily due to poor samples rather than to errors in technique.

By means of the foregoing method, the patients were classified according to the highest sputum count observed at any time during the production of rusty sputum. This count was used whether or not the number of organisms was subsequently reduced as a result of treatment. Although 24 patients showed an increase in sputum count during the period of hospitalization, the classification of these cases on the basis of their highest count did not materially affect the final results. Patients whose sputum counts did not exceed 10 per oil immersion field were classified in group $A$; those with 11 to 30 organisms were placed in group B; those with counts ranging from 31 to

\footnotetext{
2 Watery specimens were permitted to dry before the addition of stain.
} 
75 were included in group $C$; and those with more than 75 pneumococci were placed in group D.8

\section{RESULTS}

The following report is based upon 678 roentgenographically proved cases of pneumococcic pneumonia, admitted to the Detroit Receiving Hospital between January of 1938 and May of 1942. It includes all patients, except type III, in whom the sputum was studied, irrespective of complications, length of hospitalization, and cause of death. Of the total cases studied, 78 per cent (groups A and B) were classified as mild to moderately severe, and 22 per cent (groups $C$ and D) as severe to overwhelmed. Table I reveals the close correlation between the number of pneumococci per field in rusty sputum and the outcome of the pneumonia. The fatality rate, as shown in Table I, was only 2 per cent in group A, 9 per cent in group B, 30 per cent in group C, and 77 per cent in group D. These significant differences obtained, despite the fact that the majority of cases in group A received either supportive therapy or small doses of serum, whereas

TABLE I

Classification of cases by sputum groups

\begin{tabular}{c|l|r|r|r|r}
\hline \hline \multirow{2}{*}{$\begin{array}{c}\text { Sputum } \\
\text { group }\end{array}$} & \multicolumn{2}{|c|}{$\begin{array}{c}\text { Highest } \\
\text { sputum } \\
\text { count }\end{array}$} & \multicolumn{2}{|c|}{ Cases } & \multicolumn{2}{|c}{ Deaths } \\
\cline { 3 - 6 } \cline { 3 - 6 } & $\begin{array}{c}\text { Num- } \\
\text { ber }\end{array}$ & $\begin{array}{c}\text { Per cent } \\
\text { of total }\end{array}$ & $\begin{array}{c}\text { Num- } \\
\text { ber }\end{array}$ & $\begin{array}{c}\text { Per cent } \\
\text { fatality }\end{array}$ \\
\hline A & 10 or less & 320 & 47 & 6 & 2 \\
B & 11 to 30 & 210 & 31 & 18 & 9 \\
C & 31 to 75 & 101 & 15 & 30 & 30 \\
D & 76 and over & 47 & 7 & 36 & 77 \\
\hline Total & & 678 & 100 & 90 & 13 \\
\hline
\end{tabular}

most of the cases in groups $C$ and D received intensive chemotherapy, often supplemented by serum. Treatment was withheld from many patients in group A because one phase of this study was concerned with the evaluation of the sputum findings as a guide to specific therapy (7).

An analysis of the outcome in reference to ther-

\footnotetext{
8 In previous publications, only 3 groups were listed, but the number of cases has now made possible the separation into 4. This change also necessitated a shift in the range of sputum counts within a given group in order to make the differences statistically significant.

The type III cases will be considered separately.
}

apy is presented in Table II. The fatality rate in group A was as low with supportive therapy as it was with serum, sulfanilamide, and even with more modern chemotherapeutic agents. In group $B$, the clinical response to sulfapyridine, sulfathiazole, and sulfadiazine was usually more dramatic than with serum or sulfanilamide, but the final fatality rates of 9 and 7 per cent were essentially the same. The superiority of modern chemotherapeutic agents became evident in cases with more than 30 pneumococci per field. In group C, the fatality rate was 52 per cent with the older methods of treatment as compared with 20 per cent when sulfapyridine, sulfathiazole, or sulfadiazine was used. In group $\mathrm{D}$, the corresponding figures were 94 per cent and 68 per cent. The use of serum in conjunction with the more recent chemotherapeutic agents was no more effective than chemotherapy alone in cases with sputum counts over 30 per field (Table II).

The prognostic significance of the type of pneumococcus has been stressed in the literature. In the present study, we obtained a fatality rate of 11 per cent for type I and 20 per cent for type II, which is representative of the trend in other published reports. A breakdown of these figures to permit a comparison of cases whose sputum counts fell within the same range (Table III) has shown that the fatality rates of type $I$ and type II pneumonias were essentially the same as the composite figures for other types. Thus the fatality for cases with less than 30 pneumococci per field (groups A and B) was 5 per cent for type I, 4 per cent for type II, and 5 per cent for other types. The respective figures for cases with 31 to 75 pneumococci per field (group C) were 29 per cent, 33 per cent, and 30 per cent. The higher fatality rate for the entire group of 118 type II pneumonias may be explained by the fact that sputum counts above 30 were found in 32 per cent of the type II cases and in only 18 per cent of the type I cases. The results with types VII and VIII were similar to those obtained for type I. It is therefore apparent that the outcome of the pneumonia is more closely related to the sputum count than to the type of pneumococcus.

The unfavorable prognostic significance of bacteremia is universally recognized. Our fatality rate of 6 per cent among 453 cases with negative 
TABLE II

The relation of therapy to sputum counts

\begin{tabular}{|c|c|c|c|c|c|c|c|c|c|c|c|c|}
\hline \multirow{4}{*}{ Therapy } & \multicolumn{12}{|c|}{ Sputum'group } \\
\hline & \multicolumn{3}{|c|}{$\mathbf{A}$} & \multicolumn{3}{|c|}{ B } & \multicolumn{3}{|c|}{ C } & \multicolumn{3}{|c|}{$\mathbf{D}$} \\
\hline & \multirow{2}{*}{$\frac{\text { Cases }}{\substack{\text { Num- } \\
\text { ber }}}$} & \multicolumn{2}{|c|}{ Deaths } & \multirow{2}{*}{$\frac{\text { Cases }}{\substack{\text { Num- } \\
\text { ber }}}$} & \multicolumn{2}{|c|}{ Deaths } & \multirow{2}{*}{$\frac{\text { Cases }}{\substack{\text { Num- } \\
\text { ber }}}$} & \multicolumn{2}{|c|}{ Deaths } & \multirow{2}{*}{$\frac{\text { Cases }}{\underbrace{\text { Num: }}_{\text {ber }}}$} & \multicolumn{2}{|c|}{ Deaths } \\
\hline & & $\underset{\text { ber }}{\text { Num- }}$ & $\begin{array}{l}\text { Per cent } \\
\text { fatality }\end{array}$ & & $\underset{\text { ber }}{\text { Num- }}$ & $\begin{array}{l}\text { Per cent } \\
\text { fatality }\end{array}$ & & $\underset{\text { ber }}{\text { Num- }}$ & $\begin{array}{l}\text { Per cent } \\
\text { fatality }\end{array}$ & & $\underset{\text { ber }}{\text { Num- }}$ & $\begin{array}{l}\text { Per cent } \\
\text { fatality }\end{array}$ \\
\hline 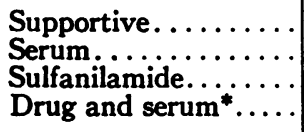 & $\begin{array}{r}75 \\
105 \\
33 \\
6\end{array}$ & $\begin{array}{l}1 \\
2 \\
0 \\
0\end{array}$ & $\begin{array}{l}1 \\
2\end{array}$ & $\begin{array}{r}2 \\
16 \\
22 \\
2\end{array}$ & $\begin{array}{l}0 \\
1 \\
2 \\
0\end{array}$ & $\begin{array}{l}6 \\
9\end{array}$ & $\begin{array}{r}1 \\
13 \\
15 \\
2\end{array}$ & $\begin{array}{l}1 \\
6 \\
8 \\
1\end{array}$ & & $\begin{array}{l}3 \\
6 \\
5 \\
2\end{array}$ & $\begin{array}{l}3 \\
6 \\
5 \\
1\end{array}$ & \\
\hline Total........... & 219 & 3 & 1 & 42 & 3 & 7 & 31 & 16 & 52 & 16 & 15 & 94 \\
\hline $\begin{array}{l}\text { Sulfapyridine } \ldots \ldots \ldots \\
\text { Sulfathiazole......... } \\
\text { Sulfadiazine........ } \\
\text { Drug and serum*.... }\end{array}$ & $\begin{array}{r}36 \\
46 \\
15 \\
4\end{array}$ & $\begin{array}{l}2 \\
0 \\
0 \\
1\end{array}$ & & $\begin{array}{r}47 \\
106 \\
7 \\
8\end{array}$ & $\begin{array}{l}3 \\
9 \\
1 \\
2\end{array}$ & $\begin{array}{l}6 \\
9\end{array}$ & $\begin{array}{r}11 \\
38 \\
5 \\
16\end{array}$ & $\begin{array}{l}2 \\
7 \\
0 \\
5\end{array}$ & 19 & $\begin{array}{r}5 \\
9 \\
2 \\
15\end{array}$ & $\begin{array}{r}5 \\
5 \\
1 \\
10\end{array}$ & \\
\hline Total........... & 101 & 3 & 3 & 168 & 15 & 9 & 70 & 14 & 20 & 31 & 21 & 68 \\
\hline Grand Total......... & 320 & 6 & 2 & 210 & 18 & 9 & 101 & 30 & 30 & 47 & 36 & 77 \\
\hline
\end{tabular}

- The term drug and serum refers to serum plus sulfanilamide in contrast to serum plus sulfapyridine, sulfathiazole, or sulfadiazine.

blood cultures, as compared with 28 per cent among 225 cases with positive cultures, is representative of reports in the recent literature. A breakdown of these figures, however, according to sputum count (Table IV) revealed only minor differences in the fatality rates of bacteremics and non-bacteremics whose sputum counts fell within the same range. Thus, in group A, the fatality rate was 2 per cent with negative blood culture and only 5 per cent with positive blood culture. In group B, the death rate was 8 per cent among non-bacteremics as compared with 10 per cent among bacteremics. In group $\mathrm{C}$, the correspond- ing figures were 23 per cent and 34 per cent; in group D, 83 per cent and 76 per cent. The greater disparity in bacteremic and non-bacteremic fatality rates for the series as a whole may be largely explained by the fact that 45 per cent of the bacteremics and only 10 per cent of the nonbacteremics fell into groups $C$ and $D$, which show a high fatality irrespective of blood culture. It is thus apparent that the outcome of pneumonia is correlated more closely with the number of pneumococci in the sputum than with the presence or absence of bacteremia.

Quantitative blood cultures were done in 165

TABLE III

The relation of type to sputum counts

\begin{tabular}{|c|c|c|c|c|c|c|c|c|c|}
\hline \multirow{3}{*}{$\underset{\substack{\text { Sputum } \\
\text { group }}}{\text { group }}$} & \multicolumn{3}{|c|}{ Type I } & \multicolumn{3}{|c|}{ Type II } & \multicolumn{3}{|c|}{ Other types } \\
\hline & \multicolumn{2}{|c|}{ Cases } & \multirow{2}{*}{$\begin{array}{l}\text { Deaths } \\
\begin{array}{l}\text { Per cent } \\
\text { fatality }\end{array}\end{array}$} & \multicolumn{2}{|c|}{ Cases } & \multirow{2}{*}{$\begin{array}{l}\text { Deaths } \\
\begin{array}{c}\text { Per cent } \\
\text { fatality }\end{array}\end{array}$} & \multicolumn{2}{|c|}{ Cases } & \multirow{2}{*}{$\begin{array}{l}\text { Deaths } \\
\begin{array}{c}\text { Per cent } \\
\text { fatality }\end{array}\end{array}$} \\
\hline & Number & $\begin{array}{l}\text { Per cent of } \\
\text { total }\end{array}$ & & Number & $\begin{array}{l}\text { Per cent of } \\
\text { total }\end{array}$ & & Number & $\begin{array}{l}\text { Per cent of } \\
\text { total }\end{array}$ & \\
\hline $\begin{array}{l}\mathbf{A} \\
\mathbf{B} \\
\mathbf{C} \\
\mathbf{D}\end{array}$ & $\begin{array}{r}73 \\
57 \\
21 \\
7\end{array}$ & $\begin{array}{r}46 \\
36 \\
13 \\
5\end{array}$ & $\begin{array}{r}4 \\
5 \\
29 \\
90\end{array}$ & $\begin{array}{l}46 \\
34 \\
24 \\
14\end{array}$ & $\begin{array}{l}39 \\
29 \\
20 \\
12\end{array}$ & $\begin{array}{r}2 \\
6 \\
33 \\
93\end{array}$ & $\begin{array}{r}320 \\
210 \\
101 \\
47\end{array}$ & $\begin{array}{r}47 \\
31 \\
15 \\
7\end{array}$ & $\begin{array}{r}2 \\
9 \\
30 \\
77\end{array}$ \\
\hline Totals & 158 & 23 & 11 & 118 & 17 & 20 & 678 & 100 & 13 \\
\hline
\end{tabular}


TABLE IV

The relation of bacteremia to sputum counts

\begin{tabular}{|c|c|c|c|c|c|c|c|c|c|c|c|}
\hline \multirow{3}{*}{$\begin{array}{c}\text { Sputum } \\
\text { group }\end{array}$} & \multicolumn{4}{|c|}{ Blood culture negative } & \multicolumn{4}{|c|}{ Blood culture positive } & \multicolumn{3}{|c|}{ Totals } \\
\hline & \multicolumn{2}{|c|}{ Cases } & \multicolumn{2}{|c|}{ Deaths } & \multicolumn{2}{|c|}{ Cases } & \multicolumn{2}{|c|}{ Deaths } & \multicolumn{2}{|c|}{ Cases } & \multirow{2}{*}{$\begin{array}{l}\text { Deaths } \\
\begin{array}{l}\text { Per cent } \\
\text { fatality }\end{array}\end{array}$} \\
\hline & Num- & $\begin{array}{l}\text { Per cent of } \\
\text { total }\end{array}$ & $\underset{\text { ber }}{\text { Num. }}$ & $\begin{array}{l}\text { Per cent } \\
\text { fatality }\end{array}$ & $\underset{\text { ber }}{\text { Num- }}$ & $\begin{array}{l}\text { Per cent of } \\
\text { total }\end{array}$ & $\underset{\text { ber }}{\text { Num- }}$ & $\begin{array}{l}\text { Per cent } \\
\text { fatality }\end{array}$ & $\underset{\text { ber }}{\text { Num- }}$ & $\begin{array}{c}\text { Per cent of } \\
\text { total }\end{array}$ & \\
\hline $\begin{array}{l}\text { A } \\
\mathbf{B} \\
\mathbf{C} \\
\mathbf{D}\end{array}$ & $\begin{array}{r}276 \\
131 \\
40 \\
6\end{array}$ & $\begin{array}{r}61 \\
29 \\
9 \\
1\end{array}$ & $\begin{array}{r}4 \\
10 \\
9 \\
5\end{array}$ & $\begin{array}{r}2 \\
8 \\
23 \\
83\end{array}$ & $\begin{array}{l}44 \\
79 \\
61 \\
41\end{array}$ & $\begin{array}{l}20 \\
35 \\
27 \\
18\end{array}$ & $\begin{array}{r}2 \\
8 \\
21 \\
31\end{array}$ & $\begin{array}{r}5 \\
10 \\
34 \\
76\end{array}$ & $\begin{array}{r}320 \\
210 \\
101 \\
47\end{array}$ & $\begin{array}{r}47 \\
31 \\
15 \\
7\end{array}$ & $\begin{array}{r}2 \\
9 \\
30 \\
77\end{array}$ \\
\hline Totals & 453 & 67 & 28 & 6 & 225 & 33 & 62 & 28 & 678 & 100 & 13 \\
\hline
\end{tabular}

of the 225 cases with bacteremia. ${ }^{5}$ The fatality rate was 19 per cent among 137 cases with less than 50 pneumococci per cc. of blood. A breakdown of these cases according to sputum counts revealed a fatality of 8 per cent in 89 cases classed in groups A and B, as compared with a rate of 35 per cent in 48 patients classed in groups $C$ and D. These data did not differ markedly from the 5 per cent fatality rate for the entire series of 530 cases falling into groups $A$ and $B$, and the 44 per cent fatality rate for the entire series of 148 cases falling into groups $C$ and D and offer further support to our contention that the outcome of pneumonia is correlated more closely with the number of pneumococci in the sputum than with the presence or absence of minor grades of bacteremia. The statistics for blood cultures exceeding 50 per cc. were inconclusive because of the small number of cases, but conformed with the generally accepted view that high grades of bacteremia have an unfavorable effect on prognosis. The fatality rate among 28 such cases was 75 per cent. A breakdown of these 28 cases according to sputum counts revealed 2 deaths ( 40 per cent) among 5 patients classed in groups A and B, and 21 deaths (91 per cent) among 23 cases in groups $C$ and D. An analysis of the deaths showed that those in groups A and B were attributable chiefly to complications, whereas the majority in $\mathrm{C}$ and $\mathrm{D}$ were due to pneumonia per se.

In Table $\mathrm{V}$, the results are analyzed according to the sputum count and the duration of the pneumonia prior to therapy. A study of this table reveals that the fatality rate was uniformly low

- We are indebted to Dr. Daniel Hasley for the data on quantitative blood cultures. in group $\mathrm{A}$ and high in group $\mathrm{D}$, regardless of the duration of the disease before the institution of therapy. The fatality rate in groups B and C was intermediate between $A$ and $D$ in both the early and late pneumonias, but tended to be lower when treatment was instituted prior to the fourth day. It should also be noted that the duration of the disease determined to some extent the group to which the patient belonged, since only 14 per cent of cases ill less than 48 hours fell into $C$ and $D$, whereas 39 per cent of those with onsets of 144 hours and over were classed in these groups; however, the outcome of the pneumonia was correlated more closely with the sputum counts than with the duration of the disease prior to therapy.

The results in reference to sputum and leukocyte counts are recorded in Table VI. It is generally recognized that the prognosis is poor in pneumonias associated with white cell counts below 5,000 per c. mm. of blood. This was especially true before the introduction of modern chemotherapy. Our fatality rate of 42 per cent in 36 such cases, as compared with 10 per cent in 505 cases with leukocytosis, is representative of the trend in other published reports; however, a breakdown of the cases according to sputum counts showed a much closer correlation of the fatality rate with the number of pneumococci in the sputum than with the leukocyte count. There were no deaths among the 15 cases with leukopenia which showed less than 30 pneumococci per field whereas there were 15 deaths ( 71 per cent) among the 21 leukopenic cases which showed more than 30 organisms per field. The apparent discrepancy in the fatality rates for the entire series of cases of leukopenia and leukocytosis can be ex- 

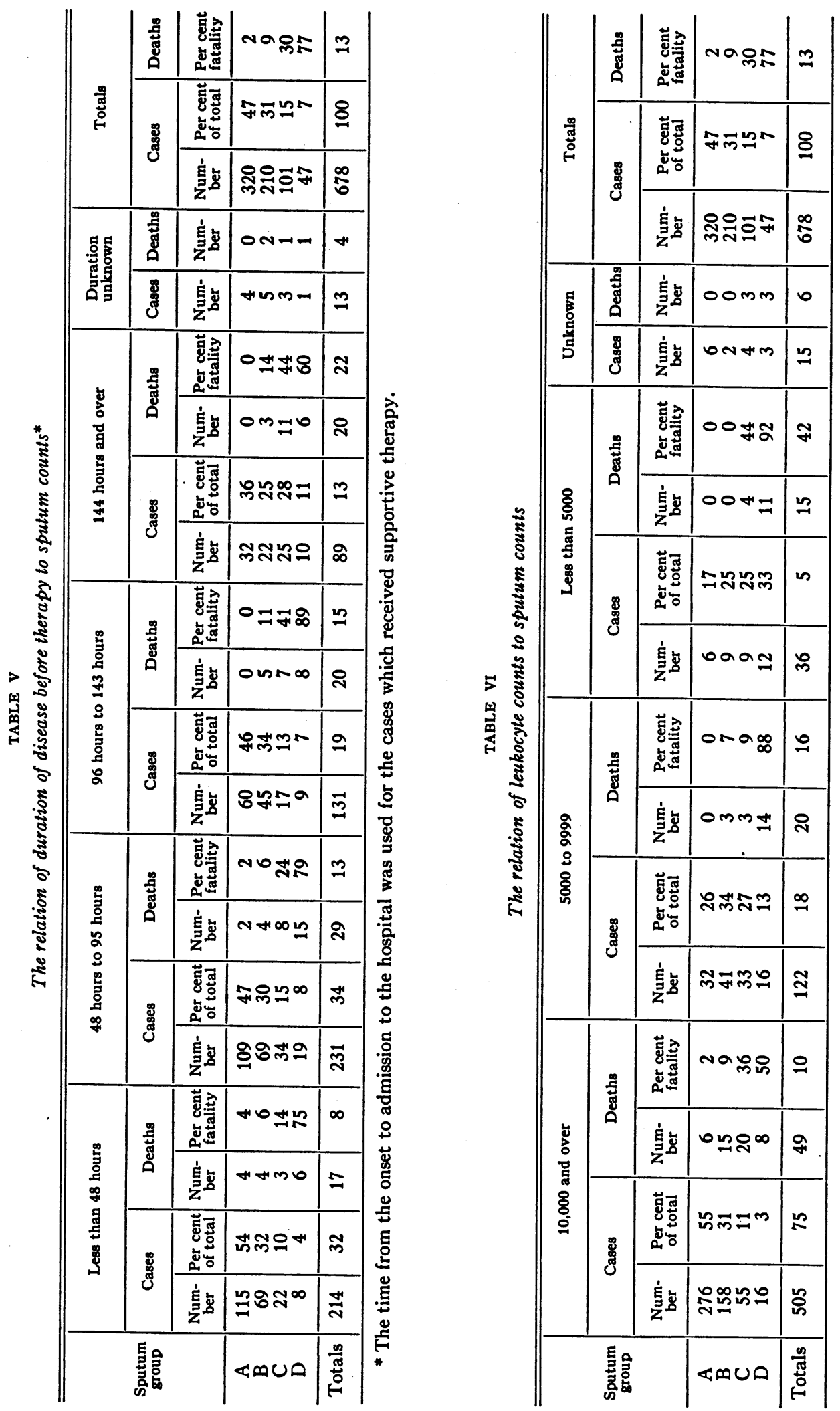
TABLE VII

The relation of age to sputum counts

\begin{tabular}{|c|c|c|c|c|c|c|c|c|c|c|c|c|c|c|c|}
\hline \multirow{3}{*}{$\begin{array}{c}\text { Sputum } \\
\text { group }\end{array}$} & \multicolumn{4}{|c|}{ Age 5 to 29 years } & \multicolumn{4}{|c|}{ Age 30 to 54 year8 } & \multicolumn{4}{|c|}{ Age 55 years and over } & \multicolumn{3}{|c|}{ Totals } \\
\hline & \multicolumn{2}{|c|}{ Cases } & \multicolumn{2}{|c|}{ Deaths } & \multicolumn{2}{|c|}{ Cases } & \multicolumn{2}{|c|}{ Deaths } & \multicolumn{2}{|c|}{ Cases } & \multicolumn{2}{|c|}{ Deaths } & \multicolumn{2}{|c|}{ Cases } & \multirow{2}{*}{ Deaths } \\
\hline & $\underset{\text { ber }}{\text { Num- }}$ & $\begin{array}{l}\text { Per cent } \\
\text { of total }\end{array}$ & $\underset{\text { ber- }}{\text { Num- }}$ & $\begin{array}{l}\text { Per cent } \\
\text { fatality }\end{array}$ & $\underset{\text { Num- }}{\text { Num- }}$ & $\begin{array}{l}\text { Per cent } \\
\text { of total }\end{array}$ & $\underset{\text { Num- }}{\text { Num- }}$ & $\begin{array}{l}\text { Per cent } \\
\text { fatality }\end{array}$ & $\underset{\text { ber }}{\text { Num- }}$ & $\begin{array}{l}\text { Per cent } \\
\text { of total }\end{array}$ & $\underset{\text { ber }}{\text { Num- }}$ & $\begin{array}{l}\text { Per cent } \\
\text { fatality }\end{array}$ & $\underset{\text { ber }}{\text { Num- }}$ & $\begin{array}{l}\text { Per cent } \\
\text { of total }\end{array}$ & \\
\hline $\begin{array}{l}\mathbf{A} \\
\mathbf{B} \\
\mathbf{C} \\
\mathbf{D}\end{array}$ & $\begin{array}{r}110 \\
60 \\
17 \\
2\end{array}$ & $\begin{array}{r}58 \\
32 \\
9 \\
1\end{array}$ & $\begin{array}{l}0 \\
1 \\
5 \\
2\end{array}$ & $\begin{array}{r}0 \\
2 \\
29 \\
100\end{array}$ & $\begin{array}{r}180 \\
124 \\
66 \\
30\end{array}$ & $\begin{array}{r}45 \\
31 \\
16 \\
8\end{array}$ & $\begin{array}{r}3 \\
9 \\
17 \\
23\end{array}$ & $\begin{array}{r}2 \\
7 \\
26 \\
77\end{array}$ & $\begin{array}{l}30 \\
26 \\
18 \\
15\end{array}$ & $\begin{array}{l}34 \\
29 \\
20 \\
17\end{array}$ & $\begin{array}{r}3 \\
8 \\
8 \\
11\end{array}$ & $\begin{array}{l}10 \\
31 \\
44 \\
73\end{array}$ & $\begin{array}{r}320 \\
210 \\
101 \\
47\end{array}$ & $\begin{array}{r}47 \\
31 \\
15 \\
7\end{array}$ & $\begin{array}{r}2 \\
9 \\
30 \\
77\end{array}$ \\
\hline Totals & 189 & 28 & 8 & 4 & 400 & 59 & 52 & 13 & 89 & 13 & 30 & 34 & 678 & 100 & 13 \\
\hline
\end{tabular}

plained by the fact that 58 per cent of the former and only 14 per cent of the latter fell into groups $\mathrm{C}$ and $\mathrm{D}$.

The relationship between the sputum counts and the age of the patients is shown in Table VII. A breakdown of the cases according to sputum groups revealed that the fatality rates correlated more closely with the number of pneumococci than they did with the factor of age. The progressive rise in fatality with age could be attributed in part to the distribution of cases within a given sputum group. Thus, 37 per cent of the oldest patients belonged to $C$ and $D$ whereas only 10 per cent of the youngest patients fell into the same groups. The patients aged 55 and over were of particular interest because the death rates of 10,31 , and 44 per cent were higher than the average values of 2 , 9 , and 30 per cent for groups A, B, and C, respectively. These discrepancies could be partially accounted for by the greater incidence of serious associated diseases such as cardiac failure, renal insufficiency, cirrhosis, and carcinoma in the group over 54 years of age.
In Table VIII, the results are analyzed according to sputum count and extent of the consolidation as revealed by physical examination and roentgenogram on admission to the hospital. When fatalities were calculated separately for cases with consolidation limited to one lobe and for those showing involvement of two or more lobes, a greater deviation from the average fatality within sputum groups was found than for any other factor studied. Thus, in group A, the fatality rate was 1 per cent when the pneumonia was confined to a single lobe and 8 per cent when it involved more than one lobe; in group B, the corresponding figures were 3 per cent and 22 per cent; in group C, they were 17 per cent and 47 per cent; and in group D, 56 per cent and 90 per cent. These data indicate that the degree of involvement before therapy was a significant factor in the outcome of the pneumonia irrespective of the sputum count. Extension of the process to additional lobes during the course of treatment occurred in only 13 per cent of the cases in groups A and B, and in 41 per cent of those in groups $C$ and $D$.

TABLE VII

The relation of involvement to sputum counts

\begin{tabular}{|c|c|c|c|c|c|c|c|c|c|c|c|}
\hline \multirow{3}{*}{$\underset{\text { Spoup }}{\text { Sputum }}$} & \multicolumn{4}{|c|}{ One or less lobes } & \multicolumn{4}{|c|}{ More than one lobe } & \multicolumn{3}{|c|}{ Totals } \\
\hline & \multicolumn{2}{|r|}{ Cases } & \multicolumn{2}{|c|}{ Deaths } & \multicolumn{2}{|c|}{ Cases } & \multicolumn{2}{|c|}{ Deaths } & \multicolumn{2}{|r|}{ Cases } & \multirow{2}{*}{$\begin{array}{l}\text { Deaths } \\
\begin{array}{l}\text { Per cen } \\
\text { fatality }\end{array}\end{array}$} \\
\hline & $\underset{\text { ber }}{\text { Num- }}$ & $\begin{array}{c}\text { Per cent of } \\
\text { total }\end{array}$ & $\underset{\text { ber }}{\text { Num- }}$ & $\begin{array}{l}\text { Per cent } \\
\text { fatality }\end{array}$ & $\underset{\text { ber }}{\text { Num- }}$ & $\begin{array}{c}\text { Per cent of } \\
\text { total }\end{array}$ & Num- & $\begin{array}{l}\text { Per cent } \\
\text { fatality }\end{array}$ & $\underset{\text { ber }}{\text { Num- }}$ & $\begin{array}{c}\text { Per cent of } \\
\text { total }\end{array}$ & \\
\hline $\begin{array}{l}\mathbf{A} \\
\mathbf{B} \\
\mathbf{C} \\
\mathbf{D}\end{array}$ & $\begin{array}{r}282 \\
151 \\
58 \\
18\end{array}$ & $\begin{array}{r}55 \\
30 \\
11 \\
4\end{array}$ & $\begin{array}{r}3 \\
5 \\
10 \\
10\end{array}$ & $\begin{array}{r}1 \\
3 \\
17 \\
56\end{array}$ & $\begin{array}{l}38 \\
59 \\
43 \\
29\end{array}$ & $\begin{array}{l}23 \\
35 \\
25 \\
17\end{array}$ & $\begin{array}{r}3 \\
13 \\
20 \\
26\end{array}$ & $\begin{array}{r}8 \\
22 \\
47 \\
90\end{array}$ & $\begin{array}{r}320 \\
210 \\
101 \\
47\end{array}$ & $\begin{array}{r}47 \\
31 \\
15 \\
7\end{array}$ & $\begin{array}{r}2 \\
9 \\
30 \\
77\end{array}$ \\
\hline Totals & 509 & 75 & 28 & 6 & 169 & 25 & 62 & 37 & 678 & 100 & 13 \\
\hline
\end{tabular}


Sterile effusion, hepatitis, or purulent complications developed in 11 per cent of the cases in A and $B$, and in 32 per cent of those in C and D.

\section{DISCUSSION}

The correlation of the sputum counts with other established criteria of prognostic significance was undertaken with the expectation that all factors would contribute substantially to the final fatality rate in pneumonia. It was surprising to find that type, bacteremia, leukopenia, and late pneumonia were of minor importance when the cases were broken down according to the number of pneumococci in the sputum (Tables III, IV, V, and VI). These factors have gradually lost their prognostic significance with the advent of more effective forms of therapy. The increased fatality rates that still prevail in the presence of bacteremia leukopenia, etc., can be explained in part by their frequent association with high sputum counts. Thus, the fatality of 28 per cent among bacteremics was principally due to the fact that 45 per cent of the cases fell into the sputum groups $\mathrm{C}$ and $\mathrm{D}$ which accounted for 52 of the 62 deaths. On the other hand, the relatively low non-bacteremic fatality rate of 6 per cent was largely due to the fact that only 10 per cent of the patients fell into groups $C$ and $D$. This small minority accounted for half of the non-bacteremic deaths, but their significance was statistically obscured by the remaining 90 per cent of the cases in groups A and B. Actually, the fatality rate was over three times as high among the 46 patients with negative blood cultures in groups $C$ and $D$ as that among the 123 cases with positive blood cultures in groups $\mathrm{A}$ and $\mathrm{B}$. The differences in fatality among the common types of pneumococci could also be explained on the basis of the percentage distribution of cases in the various sputum groups. The abnormally high fatality rates in patients with types II and III pneumonia have, in the past, been responsible for the emphasis placed on type. The outcome in type III can be attributed, as shown in the following paper, to the capacity of this pneumococcus to form excessive amounts of capsular polysaccharide in the sputum and lungs, whereas the present study has shown that the fatality in type II pneumonia was due (Table III) to the greater proportion of cases with more than 30 pneumococci per field, as compared with other types. The fact that the capsule of the type II pneumococcus is larger than any other except that of type III may be responsible for its ability to multiply in the lung and thus for the higher incidence of cases with sputum counts over 30 . From a practical point of view, the outcome in type II, as in types other than III, depends primarily on the number of pneumococci in the sputum of a particular patient during the course of the pneumonia.

The results of the analysis have revealed that age and the degree of involvement were factors which significantly influenced the fatality rates within the four sputum groups. The increase in fatality with age was due chiefly to a corresponding rise in the incidence of groups $C$ and $D$ and partially to the degenerative diseases associated with old age. Some of the critically ill patients over 54 years of age produced a purulent sputum which never became rusty. These patients were unsuitable for study by the present method and it is entirely possible that they may ultimately be placed in a separate and distinct category. We were surprised to find that the extent of consolidation was next in importance to sputum count in determining the outcome of the pneumonia. When fatality rates were calculated by sputum groups, significant differences were noted between the cases with consolidation limited to one lobe and those with involvement of two or more lobes. These findings suggest that the outcome of pneumonia may be even more closely related to the total number of pneumococci in the two lungs than to their concentration in rusty sputum. There is some evidence to support this view since autopsy studies of fulminating cases have shown that pneumococci are distributed fairly uniformly throughout areas of gray hepatization, red hepatization, and inflammatory edema (2). Therefore, one might expect to find more pneumococci in the lungs with multiple than with single lobe involvement even though the sputum counts are the same. Another factor which may contribute toward the higher fatality rate is the degree of anoxemia associated with extensive pneumonia.

The utilization of the sputum as a method of prognosis in pneumonia has simplified the statistical approach to this disease. Because of the narrow fatality ranges involved, the generally ac-. cepted practice of alternating cases and analyzing 
them by type, bacteremia, leukopenia, lobe involvement, duration of disease, therapy, etc., requires unusually large numbers of patients in order to prove the significance of any particular factor. The division into sputum groups, however, permits an unlimited range of fatalities depending only upon the number of cases studied. Such a classification could be duplicated by various investigators and in all probability would not be influenced by seasonal, yearly, or community variations in the virulence of the disease, nor would the usual separation, according to type, bacteremia, leukocyte count, or duration of the disease, be required in order to obtain statistically significant results. Since the primary objective of all studies is to reduce the fatality rate in pneumonia, the division into sputum groups would permit an accurate evaluation of therapeutic agents with greater safety and with relatively few cases. All new drugs submitted for clinical trial would first receive preliminary study in selected patients with initial sputum counts of 20 or less. The efficacy of the drugs could be evaluated in these patients by repeated examination of sputum to determine whether or not they were capable of reducing the number of pneumococci as rapidly as sulfathiazole or sulfadiazine. If the sputum count failed to decrease, or actually increased within a specified time, therapeutic agents of proven value could be readily substituted without subjecting the patients to unnecessary hazards $(5,7)$. The most promising drugs could then be studied in cases with more than 30 pneumococci per field in the hope that they might effect a significant reduction of the high fatality rate which still obtains with sulfathiazole and sulfadiazine in this group.

\section{SUMMARY}

The average number of pneumococci per oil immersion field in Wright-stained smears of rusty sputum was determined at 12 -hour intervals in 678 cases of pneumococcic pneumonia, exclusive of type III. The close relationship between the highest sputum count during the course of the disease, and the outcome, was shown by the fact that the fatality rate was 2 per cent when the pneumococci did not exceed 10 per field, 9 per cent when 11 to 30 were present, 30 per cent when 31 to 75 organisms were found, and 77 per cent when the number exceeded 75 . The fatality rate was uniformly low in patients with less than 30 pneumococci per field and uniformly high in those with sputum counts above 30 , regardless of the type of pneumococcus, duration of the disease prior to therapy, leukocyte count, and blood culture. The unfavorable prognosis usually attributed to type, bacteremia, leukopenia, and late pneumonia, was due chiefly to the higher incidence of sputum counts over 30 per field in such cases. On the other hand, a comparison of cases whose sputum counts fell within the same range showed that age and extent of consolidation had a definite effect upon the outcome since the fatality rate was significantly higher in patients over 54 or in those with consolidation of 2 or more lobes on admission to the hospital. It was therefore concluded that the number of pneumococci in the sputum had the greatest influence on prognosis and that the most important accessory factors were the extent of involvement and the age of the patient. It was also found that modern chemotherapeutic agents did not appreciably reduce the fatality rate in cases with sputum counts below 30 , but were distinctly superior to sulfanilamide and serum in cases with counts above 30. The combination of serum and drugs appeared to be no more effective in the latter group than chemotherapy alone.

The authors are deeply indebted to Dr. A. B. Mitchell for his assistance and advice in the preparation and analysis of the tables.

\section{BIBLIOGRAPHY}

1. Frisch, A. W., Sputum studies in pneumonia as an aid in prognosis. Am. J. Clin. Path., 1940, 10, 472.

2. Frisch, A. W., Autopsy studies in pneumococcic pneumonia. Am. J. Clin. Path. (In press.)

3. Frisch, A. W., Sputum studies in pneumonia: The effect of sulfanilamide. J. Lab. and Clin. Med., 1940, 25, 361.

4. Frisch, A. W., Sputum studies in lobar pneumonia: Phagocytosis and the effect of serum therapy. Proc. Soc. Exper. Biol. and Med., 1938, 39, 473.

5. Frisch, A. W., Sputum studies in pneumonia: The effect of sulfapyridine and sulfathiazole. Am. J. Clin. Path., 1942, 12, 16.

6. Frisch, A. W., Sputum studies in pneumonia : In vivo and in vitro susceptibility of pneumococci to sulfapyridine and sulfathiazole. Am. J. Clin. Path., 1941, 11, 797.

7. Frisch, A. W., and Price, A. E., Sputum studies in pneumonia: The selection of therapy. Arin. Int. Med., 1941, 15, 987. 